\title{
Tax Harmonization in the EU versus Canons of Taxation
}

\author{
Jolanta Iwin-Garzyńska \\ Department of Corporate Finance and Taxation, Faculty of Economics and Management, University of Szczecin
}

\begin{abstract}
One of the main objectives to be accomplished by the European Union law is to eliminate barriers to the functioning of domestic market and in particular improve the competitiveness of enterprises. After several years of efforts, on 16 March 2011 the European Commission approved a proposal for the directive on a Common Consolidated Corporate Tax Base which is to remove obstacles to the functioning of internal market and increase tax harmonization in the $E U$. The paper addresses issues relating to tax in corporate finance. Canons of taxation will be discussed and special emphasis will be placed on principles behind formulating fiscal law provisions (including the EU law). Furthermore, the article presents the results of surveys into the importance of taxation cannons for Polish and EU companies.
\end{abstract}

Keywords: tax harmonization, canons of taxation, corporate finance

\section{Introduction}

Financial crisis faced by the European Union has revealed a problem of tax systems that are in operation in the Member States. Difficulties encountered by enterprises stem from different guidelines on calculating corporate income tax and the impossibility of consolidating financial statements for tax purposes. This problem is faced not only by transnational corporations, but all entities (legal persons) conducting activity in the European Union.

One of the main objectives to be accomplished by the European Union law is to remove barriers to the functioning of domestic market and particularly enhance the competitiveness of enterprises. In this context, the concept of Common
Consolidated Corporate Tax Base (CCCTB) has been developed. Its role in a comprehensive reform of tax law is undeniable. The reform is to improve the competitiveness of the EU enterprises. CCCTB concept may become a new quality in tax system. After several years of efforts, on 16 March 2011 the European Commission approved a proposal for the directive on a Common Consolidated Corporate Tax Base.

The article is aimed at presenting the essence of Common Consolidated Corporate Tax Base (CCCTB) in the theory of corporate finance and its relevance to firms, based on the survey of companies operating in Poland and other Member States. Table 1 presents structural characteristics of Polish enterprises participating in the survey.

Table 1: Structural characteristics of Polish enterprises participating in the survey (percentage share)

\begin{tabular}{|c|c|c|c|c|c|c|}
\hline \multirow[t]{2}{*}{ Type of organization } & $\begin{array}{c}\text { Joint-stock } \\
\text { company }\end{array}$ & $\begin{array}{c}\text { Limited liability com- } \\
\text { pany }\end{array}$ & $\begin{array}{c}\text { Cooperative } \\
\text { society }\end{array}$ & \multicolumn{2}{|r|}{ Other } & Total \\
\hline & 3.57 & 82.15 & 3.57 & & 10.71 & 100 \\
\hline \multirow{2}{*}{ Position } & Tax manager & Chief financial officer & Chief accountant & \multicolumn{2}{|c|}{ Another position } & \\
\hline & 3.57 & 1.79 & 60.71 & \multicolumn{2}{|r|}{33.93} & 100 \\
\hline \multirow[t]{2}{*}{ Number of employees } & Up to 9 employees & Up to 49 employees & Up to 100 employees & $\begin{array}{r}\text { Up to } 250 \\
\text { employees }\end{array}$ & $\begin{array}{c}\begin{array}{c}\text { More than } 250 \\
\text { employees }\end{array} \\
\end{array}$ & \\
\hline & 37.5 & 41.07 & 7.14 & 8.93 & 5.36 & 100 \\
\hline \multirow{2}{*}{ Period of activity } & Less than 3 years & Between 3 and 5 years & Between 5 and 10 years & \multicolumn{2}{|c|}{ More than 10 years } & \\
\hline & 12.5 & 16.07 & 41.07 & \multicolumn{2}{|r|}{30.36} & 100 \\
\hline \multirow{2}{*}{ Type of activity } & Production & Trade & Construction & Service & Other & \\
\hline & 8.93 & 23.21 & 12.5 & 35.71 & 19.65 & 100 \\
\hline
\end{tabular}

Source: Based on the questionnaire survey

Limited liability companies constituted the majority of respondents participating in the survey. This is due to the fact that this form of business activity is most popular among entities that have legal personality. Another reason behind such a conclusion is that small enterprises, namely employing up to 49 persons, represented the highest percentage of respondents. Furthermore, questionnaires were mainly filled in by chief financial officers. In small companies they are responsible for tax issues. Nevertheless, this is favourable in the context of the survey and its representativeness. So is the period of activity which, in the case of most respondents, exceeded 5 years, i.e. was rather long. Table 2 presents structural characteristics of enterprises operating in the Member States that have responded to the survey. 


\section{International Journal of Science and Research (IJSR) \\ ISSN (Online): 2319-7064}

Index Copernicus Value (2013): 6.14 | Impact Factor (2015): 6.391

Table 2: Structural characteristics of the EU enterprises participating in the survey (percentage share)

\begin{tabular}{|c|c|c|c|c|c|c|}
\hline \multirow[t]{2}{*}{$\begin{array}{c}\text { Type of } \\
\text { organization }\end{array}$} & $\begin{array}{c}\text { Joint-stock com- } \\
\text { pany }\end{array}$ & $\begin{array}{c}\text { Limited liability } \\
\text { company }\end{array}$ & Cooperative society & \multicolumn{2}{|r|}{ Other } & Total \\
\hline & 50 & 35.71 & 0 & \multicolumn{2}{|r|}{14.29} & 100 \\
\hline \multirow{2}{*}{ Position } & Tax manager & Chief financial officer & Chief accountant & \multicolumn{2}{|c|}{ Another position } & \\
\hline & 17.86 & 46.43 & 10.71 & \multicolumn{2}{|r|}{25} & 100 \\
\hline \multirow{2}{*}{$\begin{array}{l}\text { Number of } \\
\text { employees }\end{array}$} & Up to 9 employees & Up to 49 employees & Up to 100 employees & Up to 250 employees & More than 250 employees & \\
\hline & 32.14 & 0 & 0 & 0 & 67.86 & 100 \\
\hline \multirow{2}{*}{$\begin{array}{c}\text { Period of } \\
\text { activity }\end{array}$} & $\begin{array}{c}\text { Less than } \\
3 \text { years }\end{array}$ & Between 3 and 5 years & Between 5 and 10 years & \multicolumn{2}{|c|}{ More than 10 years } & \\
\hline & 0 & 35.71 & 0 & \multicolumn{2}{|r|}{64.29} & 100 \\
\hline \multirow{2}{*}{$\begin{array}{l}\text { Type of } \\
\text { activity }\end{array}$} & Production & Trade & Construction & Service & Other & \\
\hline & 21.43 & 7.14 & 21.43 & 42.86 & 7.14 & 100 \\
\hline
\end{tabular}

Source: based on the questionnaire survey

Unlike Polish companies, the majority of EU entities were joint stock companies. These are large entities and firms employing more than 250 persons represented the highest percentage of respondents. Questionnaires were mainly filled in by chief financial officers, i.e. employees responsible for tax issues. In the companies under discussion, accounting and taxes are separate departments. The latter are managed by chief financial officers since tax payment has a direct effect on firm's liquidity and financial standing.

According to the judgment of the Court of Justice of the European Union, ,, Although direct taxation falls within their competence, the Member States must nonetheless exercise that competence consistently with Community law" [Judgment of the Court of 14 February 1995 Finanzamt Köln-Altstadt vs. Roland Schumacker Case C-279/93; and Judgment of the Court of 4 October 1991 the European Commission vs. the United Kingdom, Case C-246/89, See: p. I-4585, section 12]. This is a recommendation for Common Consolidated Corporate Tax Base.

\section{Cannons of taxation in the financial essence of tax and CCCTB concept}

Taxation system, composed by various tax titles, should be based on certain cannons. These are fundamental rules that govern tax issues in the enterprise, the state and the EU. An important aim is to seek effective income tax system and thereby include the tax cannons in the concept of CССТВ.

Cannons of taxation are not a closed catalogue. This is the knowledge that is not subject to change. It represents phenomena emerging in social and economic reality (A. Gomułowicz, 2001, p. 12). Therefore, regardless of political and financial situation of the European Union, the concept of CCCTB should be developed in line with fundamental cannons of taxation and implemented in such a fashion in the future.

Adam Smith is considered one of the best known authors of taxation principles. It was him who formulated four cannons of taxation, namely cannon of equality, cannon of certainty, cannon of convenience and cannon of economy. Fundamental in itself, the cannon of equality entails the apportionment of tax burdens in line with the assumption that taxes are universal and proportional to one's income. As far as CCCTB is concerned, the aforementioned principle is par- ticularly significant since it calls for equal standards to be met by all enterprises operating in the European Union. To be more specific, the companies should pay their income taxes in line with the same principles (adjusted only to income bracket). Such a recommendation justifies excluding income tax from the list of harmonized tax rates.

Tax certainty consists in determining the maturity date, method of payment and amount of tax based on clearly and explicitly formulated legal regulations. In fact, this is the objective of the concept under discussion. One of its main assumptions is to provide transparent principles of corporate taxation, regardless of the Member State in which a given enterprise has its establishment and the countries with which this enterprise makes transactions.

The cannon of convenience is to provide tax payers with the most suitable (for them) method and place of payment and maturity date. On the other hand, the cannon of economy entails the minimization of tax collection costs for tax payers, the state and the entire European Union.

In the second half of the $19^{\text {th }}$ century, Wagner modified the principles of taxation and divided them into the following four groups: fiscal, economic, equity and technical.

Taxation cannons are to guarantee that a proper amount of tax revenues is paid into the state budget. On the other hand, the significance of economic principle (referring to the integrity and protection over tax sources) involves construing taxes in such a way so that entrepreneurs are able to multiply their capital. As for the cannon of equity, Wagner calls for the universality of taxation and eliminating excessive financial differences among society members.

As for the financial essence of tax and the concept of common consolidated corporate tax base, these principles are particularly relevant. Uniform taxation system should guarantee the effectiveness of tax source as well as the stability of budget revenues both in the country where the company has its establishment as well as in the entire European Union. Furthermore, unitary tax system ought to facilitate economic development of enterprises, and tax must not restrict their freedom. The last-mentioned group of taxation cannons presented by Wagner are technical principles (including convenience, certainty, economy). These are similar to postulates formulated by Smith. Nevertheless, in Wagner's case, 


\section{International Journal of Science and Research (IJSR) ISSN (Online): 2319-7064 \\ Index Copernicus Value (2013): 6.14 | Impact Factor (2015): 6.391}

this cannon refers both to tax payers and tax authorities (A. Gomułowicz, J. Małecki, 2002, p. 64).

The idea behind introducing common consolidated corporate tax base in enterprises operating in the European Union has its origin the cannon of certainty. According to this cannon, all entrepreneurs managing their business in the EU should be sure about the principles that underlie tax imposition. The cannon of certainty, formulated by Smith, is a protest against tax abuse by tax authorities. Abuse cases are possible due to the arbitrariness of tax imposition. According to Smith, certainty principle is to prevent from imposing taxes in the amount defined by law provisions, and at the same time protect tax payers from arbitrary actions taken by tax authorities. Understood by Wagner, tax certainty is provided if tax regulations are formulated in plain language, which enables tax payers to understand and get to know them in advance, and tax authorities act only on the basis of these regulations. Wagner suggests general and system solutions since tax infringes personal and economic interests. Thereby only a specific amount of tax shall be paid (A. Gomułowicz, J. Małecki, 2002, p. 24). According to Neumark, the more comprehensible, clear and precise the tax act is, the greater the awareness of obligations to be met by tax payers and the less the abuse cases stemming from extremely fiscal interpretation of tax obligations by the respective authorities (A. Gomułowicz, J. Małecki, 2002, p. 26). Undoubtedly, such a postulate has laid foundations for the concept of common consolidated corporate tax base. It is to minimize the risk faced by enterprises, and the EU directive is to protect the tax base and particularly the right that companies have to create this base. If the cannon of certainty is violated, enterprises need to take proper counter-measures and reduce the tax risk (S. Wrzosek, 2004, p. 396).

Identifying the cannons of taxation, essential for the development and operation of tax system in line with CCCTB, it should be borne in mind that the main objective of taxation has a fiscal character. In other words, tax enables the Member States to generate budget revenue. For this purpose and for the sake of tax efficiency, tax should not exert any effect on the economy, should not perform any economic or social function. This stems from the universality of taxation. If tax is to be a common burden, it ought to be neutral against economic processes since all entities are obliged to pay taxes by virtue of law. This rule is of special importance for the development of unitary (income) tax system for enterprises operating in the European Union. Such a system will be developed through applying the principle of taxation universality.

Summing up, the role of taxation principles is unquestionable. They show what is right, just and rational in social and economic terms while creating effective and efficient [According to Wilkinson, tax system is efficient if distortions caused by its operation in economic behaviour displayed by investors, consumers and savers as well as changes in product prices are minimized. If a given type of tax alters economic behaviour displayed by tax payers (i.e. their natural preferences), additional tax burdens are being placed and thereby their prosperity is reduced to less than minimum level. Wilkinson is inclined to believe that effective actions taken by public authorities should be aimed at minimizing such distortions, due to which taxation becomes effective and neutral. M. Wilkinson, Taxation, London 1992, pp. 2223] tax system as well as introducing changes into this system (due to the changeability of socio-economic conditions). Following the cannons of taxation should facilitate the creation of fiscal environment friendly for entrepreneurship and economic development in the European Union. Therefore, it is relevant to verify if Polish and EU enterprises are familiar with solutions provided in the proposal for the directive and consider them significant from the perspective of fundamental cannons of taxation.

Table 3: Cannons of taxation - benefits accruing from implementing CCCTB in the opinion of Polish enterprises (0 - insignificant, 5 - significant).

\begin{tabular}{|c|c|c|c|c|c|c|c|c|}
\hline & 0 & 1 & 2 & 3 & 4 & 5 & $\begin{array}{c}\text { absence of } \\
\text { answer }\end{array}$ & Altogether \\
\hline $\begin{array}{l}\text { Eliminating barriers created by different domestic } \\
\text { tax systems }\end{array}$ & $5.36 \%$ & $3.57 \%$ & $7.14 \%$ & $10.71 \%$ & $12.50 \%$ & $23.21 \%$ & $37.50 \%$ & $100 \%$ \\
\hline $\begin{array}{c}\text { Administrative simplifications and reducing } \\
\text { bureaucratic burdens }\end{array}$ & $3.57 \%$ & $8.93 \%$ & $10.71 \%$ & $5.36 \%$ & $16.07 \%$ & $17.86 \%$ & $37.50 \%$ & $100 \%$ \\
\hline $\begin{array}{c}\text { Providing enterprises with permanent establish- } \\
\text { ment in different Member States with equal } \\
\text { treatment }\end{array}$ & $7.14 \%$ & $7.14 \%$ & $8.93 \%$ & $8.93 \%$ & $10.71 \%$ & $19.64 \%$ & $37.50 \%$ & $100 \%$ \\
\hline $\begin{array}{c}\text { Eliminating double taxation and dealing with tax } \\
\text { evasion }\end{array}$ & $3.57 \%$ & $3.57 \%$ & $8.93 \%$ & $3.57 \%$ & $8.93 \%$ & $33.93 \%$ & $37.50 \%$ & $100 \%$ \\
\hline $\begin{array}{l}\text { Better utilization of capital, growth of competi- } \\
\text { tiveness, new jobs }\end{array}$ & $1.79 \%$ & $8.93 \%$ & $10.71 \%$ & $12.50 \%$ & $14.29 \%$ & $14.29 \%$ & $37.50 \%$ & $100 \%$ \\
\hline Formulating a more transparent tax policy & $1.79 \%$ & $3.57 \%$ & $3.57 \%$ & $10.71 \%$ & $17.86 \%$ & $25.00 \%$ & $37.50 \%$ & $100 \%$ \\
\hline Cross-border equalization of profits and losses & $7.14 \%$ & $10.71 \%$ & $8.93 \%$ & $7.14 \%$ & $7.14 \%$ & $21.43 \%$ & $37.50 \%$ & $100 \%$ \\
\hline
\end{tabular}

Source: based on the questionnaire survey

Polish enterprises regard solutions proposed in the proposal for the directive as significant for the development of transparent tax policy and eliminating double taxation. This is an important signal that the aforementioned entities expect tax system to be stable and transparent. It is beyond any doubt that such expectations stem from the cannon of generality and equality. Furthermore, entrepreneurs are inclined to believe that introducing such a system will facilitate the elimination of barriers created by particular tax systems. They consider the proposed concept significant for adminis- 


\section{International Journal of Science and Research (IJSR) \\ ISSN (Online): 2319-7064 \\ Index Copernicus Value (2013): 6.14 | Impact Factor (2015): 6.391}

trative simplifications and reducing bureaucratic burdens, which is in line with the cannon of economy and efficiency. Nearly one-third of enterprises participating in the survey declare that the concept under discussion will enable to deal with double taxation and tax evasion, which entails that the cannons of equality, universality and fairness are the most significant in the opinion of the aforementioned entities. Table 4 shows answers provided by enterprises operating in the European Union.

Table 4: Cannons of taxation - benefits accruing from implementing CCCTB in the opinion of the EU (except for Poland) enterprises ( 0 - insignificant, 5 - significant).

\begin{tabular}{|c|c|c|c|c|c|c|c|c|}
\hline & 0 & 1 & 2 & 3 & 4 & 5 & $\begin{array}{c}\text { absence } \\
\text { of answer }\end{array}$ & Total \\
\hline $\begin{array}{l}\text { Eliminating barriers created by different domes- } \\
\text { tic tax systems }\end{array}$ & $12.50 \%$ & $16.60 \%$ & $16.60 \%$ & $12.50 \%$ & $16.60 \%$ & $8.30 \%$ & $16.40 \%$ & $100 \%$ \\
\hline $\begin{array}{c}\text { Administrative simplifications and reducing } \\
\text { bureaucratic burdens }\end{array}$ & $16.60 \%$ & $8.33 \%$ & $16.60 \%$ & $12.50 \%$ & $8.33 \%$ & $12.50 \%$ & $24.74 \%$ & $100 \%$ \\
\hline $\begin{array}{c}\text { Providing enterprises with permanent establish- } \\
\text { ment in different Member States with equal } \\
\text { treatment }\end{array}$ & $12.50 \%$ & $0.00 \%$ & $12.50 \%$ & $4.17 \%$ & $16.60 \%$ & $12.50 \%$ & $41.73 \%$ & $100 \%$ \\
\hline $\begin{array}{l}\text { Eliminating double taxation and dealing with tax } \\
\text { evasion }\end{array}$ & $8.33 \%$ & $8.33 \%$ & $16.60 \%$ & $12.50 \%$ & $12.50 \%$ & $8.33 \%$ & $33.50 \%$ & $100 \%$ \\
\hline $\begin{array}{c}\text { Better utilization of capital, growth of competi- } \\
\text { tiveness, new jobs }\end{array}$ & $16.60 \%$ & $0.00 \%$ & $16.60 \%$ & $4.17 \%$ & $8.33 \%$ & $12.50 \%$ & $41.50 \%$ & $100 \%$ \\
\hline Formulating a more transparent tax policy & $12.50 \%$ & $8.33 \%$ & $16.60 \%$ & $8.33 \%$ & $16.60 \%$ & $12.50 \%$ & $25.50 \%$ & $100 \%$ \\
\hline Cross-border equalization of profits and losses & $12.50 \%$ & $8.33 \%$ & $16.60 \%$ & $20.83 \%$ & $12.50 \%$ & $12.50 \%$ & $16.50 \%$ & $100 \%$ \\
\hline
\end{tabular}

Source: based on the questionnaire survey

EU entrepreneurs did not provide answers to all the questions. The majority of respondents expressed their opinions about eliminating barriers created by different domestic tax systems as well as cross-border equalization of profits and losses. Enterprises operating in the EU are inclined to believe that the concept of CCСТB may be useful in the context of the aforementioned two aspects. These two issues are particularly significant for enterprises under discussion. Furthermore, tax burdens created by twenty-seven different income tax systems are faced particularly by entities that conduct cross-border activity. Another factors important in the opinion of the EU companies were: administrative simplifications, reducing bureaucratic burdens and greater transparency of tax policy. Analysing the answers provided, it can be noticed that the above issues are of major importance. A new concept of income tax may give rise to administrative simplifications following from the need for simplicity and transparency of tax system. However, EU enterprises' opinions about administrative simplifications reveal they do not believe that the concept of CCCTB will change something in this respect. In fact, they are afraid that administrative and bureaucratic costs may increase. On the contrary, EU entrepreneurs are positive about the possibility of enhancing the transparency of tax policy. In other words, they call for applying the principle of transparency of corporate income tax system.

The neutrality of tax against economic processes should be a reason behind striving for the harmonization of taxation in the European Union. Such neutrality entails that tax does not exert any effect on decisions made by entrepreneurs about the legal form, business location or method of financing [Company Taxation in the Internal Market, SEC (2001) 1681, p. 2]. Such a system of fiscal law may be referred to as economic neutrality of tax law.
In order to get to know the influence that taxation has on decisions taken by entrepreneurs and their activity, in 2004 the European Commission conducted a survey in which seven hundred entities participated from the then fourteen Member States (except for Luxembourg). The results were published in European Tax Survey [European Tax Survey, SEC (2004) 112/2 quoted after: M. Supera-Markowska (2010), Wspólna Skonsolidowana Podstawa Opodatkowania jako koncepcja harmonizacji opodatkowania korporacyjnego w UE, C.H. Beck, Warszawa, p. 32]. The analysis of respondents' declarations enable one to state that taxation is a significant factor determining entrepreneurs' decisions about business location. According to $87.3 \%$ of entities responding to the survey, tax-related issues has had an impact on their decisions about the form of business activity conducted abroad. Such a situation is contradictory to the principle of taxation neutrality and, most of all, should not take place on the internal market.

Common currency area has been created in the European Union relatively recently. Therefore, theoretical discussion and findings of empirical research provide a number of interesting cases of countries with one currency but different tax systems operating in their particular regions. Special attention should be paid to experience shared by the United States of America (R. Baldwin, P. Krugman 2004, pp.1-23) and Canada (J. Mintz, 2004, pp. 221-234) (federal states with a single currency, yet different tax jurisdictions) in the case of which tax harmonization was not successful. It is there that tax competition among different states (provinces) is observed. The U.S. literature on the subject presents a great deal of information concerning the subject matter and results of empirical research conducted in this scope (W.E. Oates 2001, pp.507-512). The findings of these research are relevant since they provide a foundation for recommendations to be followed by the EU common currency area (G.R. 


\section{International Journal of Science and Research (IJSR) \\ ISSN (Online): 2319-7064 \\ Index Copernicus Value (2013): 6.14 | Impact Factor (2015): 6.391}

Zodrow, 2003, pp. 651-671). Nevertheless, controversy over the harmonization of tax systems as well as advantages and disadvantages of tax competition referred to in such research should not be neglected.

\section{Common Consolidated Corporate Tax Base - fundamental assumptions}

In a document entitled "A Common Consolidated EU Corporate Tax Base [A Common Consolidated EU Corporate Tax Base, Commission Non-Paper to informal Ecofin Council, 10 and 11 September 2004, http://ec.europe.eu/taxation_customs]" published on 7th July 2004 includes the assumptions of the concept aimed at reducing the costs and barriers to business activity in the European Union. On 16th March 2011[Proposal for a Council Directive on a Common Consolidated Corporate Tax Base of 16 March 2011\{SEC(2011) 315\}\{SEC(2011) 316\}] the European Commission submitted a proposal for the directive on a Common Consolidated Corporate Tax Base (CCCTB). According to the proposal, the main goal of the concept is to eliminate at least some major tax problems impeding economic growth on the EU single market. Due to the lack of uniform corporate tax regulations, interdependence of domestic tax systems often results in double taxation. Hence, enterprises have to deal with heavy administrative burdens and high costs associated with conforming to tax regulations. Such a state of affairs discourages companies from making investments in the EU and consequently hinders the achievement of priorities included in ,Europe 2020" - a strategy for smart, sustainable and inclusive growth [The strategy is aimed at smart, sustainable and inclusive growth. The Strategy Europe 2020 has defined the following three inter-related priorities:

- smart growth: development of the economy based on knowledge and innovation;

- sustainable growth: supporting the economy based on a more efficient use of resources, more environmentally friendly and more competitive;

- inclusive growth: supporting the economy characterized by a high employment rate, providing social and territorial cohesion.

Cf. Communication from the Commission EUROPE 2020 A strategy for smart, sustainable and inclusive growth COM(2010) 2020 Brussels 3.3.2010].

Common Consolidated Corporate Tax Base is a major initiative designed to eliminate obstacles to the creation of a single market [Communication from the Commission Towards a Single Market Act - For a highly competitive social market economy - 50 proposals for improving our work, business and exchanges with one another - COM(2010) 608 Brussels 27.10.2010]. It is considered [Communication from the Commission Annual Growth Survey: advancing the EU's comprehensive response to the crisis, COM(2011) 11 Brussels 12.01.2010] an initiative stimulating growth that should be undertaken in the first place in order to facilitate economic development and create new jobs. CCCTB concept would guarantee the coherence of domestic tax systems but no the harmonisation of tax rates.
According to the proposal for the directive, tax rates ought to be subject to fair competition. Different rates enable particular countries to maintain certain level of tax competition on internal market. Furthermore, fair competition based on tax rates provides a greater transparency and allows the Member States to take account of the competitiveness of their markets and budgetary requirements while determining tax rates (J. Iwin-Garzyńska, 2013, A, p. 208).

Supporting research and development is one of fundamental objectives included in the directive under discussion. As part of Common Consolidated Corporate Tax Base, all costs associated with R\&D are tax deductible expenses. For enterprises that would decide to adopt the system, such an approach will be an incentive to further investment in research and development. In case of economic losses which are subject to cross-border compensation, consolidation within the framework of CCСТB will contribute significantly to reducing the tax base. Nevertheless, the implementation of CCCTB will expand the average EU tax base mainly due to the option taken as far as the depreciation of assets is concerned.

The introduction of CCCTB would reduce or even eliminate barriers to conducting cross-border activity in the European Union. This is of profound importance for enterprises regardless of their size. In the case of small and medium-sized companies, costs involved in adjusting the activity to regulations imposed in particular countries are a major barrier. Compared to the turnover of such firms, these costs are an important item. As for large enterprises, the possibility of cross-border settlement of tax losses is the main advantage of the new solution (J. Iwin-Garzyńska, 2013, B, pp. 594602).

A system will be chosen voluntarily. Since not all enterprises conduct their activity abroad, CCCTB will not require companies which do not intend to expand their busoness outside their homelands to cover costs associated with adopting a new tax system.

Only methods for determining tax base will be subject to harmonisation. It will not be the case with financial statements. Therefore, the Member States will still apply domestic principles of financial accounting, and CCCTB will impose autonomous regulations on calculating corporate tax base. These regulations will not exert any effect on producing annual and consolidated financial reports.

As for CCCTB, certain enterprises would have to follow uniform tax rules (applicable in the entire European Union) and would deal with single tax administration (one-stop shop). Having decided to apply common consolidated corporate tax base, the company is no longer subject to domestic corporate tax system as far as all the issues regulated by joint regulations are concerned.

Enterprises conducting activity in more than one state will benefit from the possibility of cross-border loss relief and lowering the costs involved in conforming to corporate tax regulations. The possibility of direct consolidation of profits and losses for the purpose of calculating the EU tax base is a major step toward reducing overtaxation in a cross-border 


\section{International Journal of Science and Research (IJSR) \\ ISSN (Online): 2319-7064 \\ Index Copernicus Value (2013): 6.14 | Impact Factor (2015): 6.391}

context. At the same time, it is a step toward improving the existing conditions, namely in the scope of tax neutrality of domestic and cross-border activity. This will lead to a more effective fulfilment of internal market potential [Calculations made with reference to multinational enterprises operating in the EU indicate that about $50 \%$ of multinational financial groups and $17 \%$ of multinational non-financial groups may receive direct compensation for cross-border losses. Prawo podatkowe przedsiębiorców. Ed. by $\mathrm{H}$. Litwińczuk, LEX a Wolters Kluwer business, Warszawa 2013, pp. 234-235].

The main advantage of implementing CCCTB for enterprises is the reduction of costs associated with observing tax regulations. Data published by the European Commission indicates that the introduction of the aforementioned concept may lower such costs by circa 7\%. Actual reduction of the costs under discussion may have a major impact on enterprises' potential and willingness to expand their business and enter foreign markets (especially the companies that have operated only on regional markets so far) [Cf. COUNCIL DIRECTIVE on a Common Consolidated Corporate Tax Base (CCCTB); Brussels, COM(2011) 121/4, 2011/0058 (CNS) \{SEC(2011) 315\}\{SEC(2011) 316\}. According to the estimates made by the European Commission, a new regulation would enable to save about 700 million Euro annually in the European Union on the costs associated with adjusting to other fiscal systems, circa 1.3 billion Euro as a result of the consolidation of calculation rules, and nearly 1 billion Euro on cross-border activity. Experts are inclined to believe that such a solution would increase the attractiveness of the EU as a location of large-scale investments].

The directive under consideration provides a complete set of corporate tax regulations. It specifies which entities may select tax system, method of determining tax base, relief scope and methods. Furthermore, it introduces regulations on combating fraud, proposes a method for the apportionment of consolidated base, and specifies how CCCTB system is to be administered by the Member States in line with „one-stop shop” principle (J. Iwin-Garzyńska, 2012, A, pp. 47-58).

Optional implementation of СССТВ entails that it will be the 28th tax system adopted by the twenty-seven Member States. In other words, certain enterprises or individual taxpayers will choose fiscal regime referred to in the directive or follow their domestic tax systems. Therefore, the proposal is a major step toward the harmonisation of corporate income tax which, by improving the internal competitiveness of the EU, is to restrict harmful internal competition.

In the context of following the principles of income tax, and particularly the principle of tax system coherence and transparency, it should be emphasized that the directive under discussion provides a complete regulation on CCCTB. Directive on CCCTB and related issues should be implemented only when all the aspects to determining the tax base and its apportionment are known, and so are the mechanisms that underlie the functioning of administration in such the new system. Needless to say, the system has to be comprehensive and coherent (J. Iwin-Garzyńska, 2012, B).

\section{Conclusion}

Income tax system operating in the European Union requires standardization in order to be competitive compared to China, Russia, the United States of America, etc. Nowadays, the Member States are not a single organism as far as income tax is concerned. In fact, they represent twenty-seven different entities that have to compete with one another inside and outside the EU. The main objective is to harmonize corporate income tax system so that all the companies operating in the EU are provided with comparable conditions and represent one body outside the European Union. In line with CССТВ concept, tax base (i.e. principles underlying the formation of taxable income and deductible expenses) will be subject to harmonization.

The survey referred to in the present paper indicates that the proposed concept may be favourable for Polish and EU enterprises. Entrepreneurs notice benefits accruing from the suggested solutions. The questionnaire survey has enabled one to get to know general views held by Polish and EU enterprises about the proposed harmonization of income tax.

It seems that the Member States have had enough time to work on the details of the directive. However, political interests also play a crucial role. Some countries consider power to tax absolutely essential. Financial crisis, and particularly recent crisis of public finance, has revealed a number of problems with taxation. Nevertheless, the Member States want to protect their budget revenues and remain entirely autonomous in shaping income tax. It is beyond any doubt that CCCTB is a serious proposal. Hence, enterprises operating in the European Union should be aware of its implementation and take account of its possible financial implications. Nevertheless, it is difficult to define the final legal form of the directive on CCСTB or state whether it will come into force.

\section{Acknowledgement and Funds}

The paper is the outcome of research conducted as part of the project financed by MNiSW (the Ministry of Science and Higher Education) nr N N113 291337 entitled Tax potential of Polish enterprises in the context of common consolidated corporate tax base and harmonization of tax law in the European Union, project manager - prof. dr hab. Jolanta Iwin-Garzyńska, 2009-2013

\section{References}

[1] A Common Consolidated EU Corporate Tax Base, Commission Non-Paper to informal Ecofin Council, 10 and 11 September 2004.

[2] Baldwin, R., Krugman, P. (2004), Agglomeration, Integration and Tax Harmonization, European Economic Review.

[3] Company Taxation in the Internal Market, SEC (2001) 1681.

[4] European Tax Survey, SEC (2004) 112/2 
[5] Gomułowicz, A., Małecki, J. (2002), Podatki i prawo podatkowe. Wydawnictwo Prawnicze LexisNexis, Warszawa.

[6] Gomułowicz, A.(2001), Zasady podatkowe wczoraj i dziś, Dom Wydawniczy ABC, Warszawa

[7] Iwin-Garzyńska, J. (2013), Opodatkowanie przedsiębiorstw w Unii Europejskiej - założenia koncepcji wspólnej skonsolidowanej korporacyjnej podstawy opodatkowania. Opodatkowanie przedsiębiorstw. Wybrane zagadnienia. Pod red. J. Iwin-Garzyńskiej. Difin, Warszawa. A

[8] Iwin-Garzyńska, J. (2013), Wspólna skonsolidowana korporacyjna podstawa opodatkowania dla matych $i$ średnich przedsiębiorstw. W: Uwarunkowania rynkowe rozwoju mikro, małych i średnich przedsiębiorstw. Pod red. A. Bielawskiej. Zeszyty Naukowe US nr 752, Ekonomiczne problemy usług nr 102, Szczecin. B

[9] Iwin-Garzyńska, J. (2012), Wspólna Skonsolidowana korporacyjna podstawa opodatkowania szansa dla przedsiębiorstw polskich, Roczniki Naukowe Wyższej Szkoły Bankowej w Toruniu. Red. M. Dragun Gertner. Toruń: Wyższa Szkoła Bankowa w Toruniu. A

[10] Iwin-Garzyńska, J. (2012), Wspólna Skonsolidowana Korporacyjna Podstawa Opodatkowania szansa rozwoju regionu Zeszyty Naukowe Uniwersytetu Szczecińskiego; Ekonomiczne Problemy Usług nr 63, Wydawnictwo Naukowe Uniwersytetu Szczecińskiego, Szczecin. B

[11] Mintz, J. (2004), Corporate Tax Harmonization in Europe: It's All About Compliance, International Tax and Public Finance.

[12] Oates, W.E. (2001), Fiscal Competition or Harmonization? Some Reflections, National Tax Journal.

[13] Prawo podatkowe przedsiębiorców. Pod red. H. Litwińczuk, (2013), LEX a Wolters Kluwer business, Warszawa.

[14] Supera-Markowska, M. (2010), Wspólna Skonsolidowana podstawa opodatkowania jako koncepcja harmonizacji opodatkowania korporacyjnego w UE, CH Beck, Warszawa.

[15] Wilkinson, M. (1992), Taxation, London.

[16] Wrzosek, S.(2004), Analiza wrażliwości jako warunek praktycznej efektywności inwestycji rzeczowych, Zarzadzanie finansami firm - teoria i praktyka, t. 2, Praca pod red. W. Pluty, Prace Naukowe, Nr 1042, Wyd. Akademii Ekonomicznej we Wrocławiu, Wrocław.

[17] Zodrow, G.R. (2003), Tax Competition and Tax Coordination in the European Union, International Tax and Public Finance. 